\title{
Can Translation Studies become a transdiscipline? A survey of some theoretical problems related to its field of research
}

\author{
Gabriel Perez \\ Ruprecht Karls Universität Heidelberg
}

\begin{abstract}
The present study attempts to outline the scope of Translation Studies (TS) as a particularly complex field of research. Thus, this paper explores TS as a transdiscipline, regarding translation phenomena as probabilistic, not categorical phenomena. It seeks to establish the strategies that can help us to understand the transversal complexity of translation phenomena, in order to give TS a metatranslation space. It is an attempt to demonstrate that the approach to this complex research field needs transdisciplinary research strategies, including both human sciences and natural sciences. Going further, the present study overcomes the traditional division between both sciences and incorporates models such as the Third Culture (Schrödinger 1951, Snow 1959 and Brockman 1996). This study attempts to take the challenge of providing TS with an epistémé (Nouss 1995), conceived as a mental laboratory that puts in practice a family of different theories, each one with a limited scope of action. These theories will compose a complete description of the logical ways of the translatological function in society by exploring the transduction of cultural phenomena in society.
\end{abstract}

Keywords: Translation theory, Translation Studies, Meta-analysis, translatological function, transdisciplinary research

Resumo: Este trabalho pretende definir o âmbito dos estudos de tradução (ET) como uma área de pesquisa especialmente complexa. Exploram-se assim os ET como uma transdisciplina, concebendo os fenómenos tradutivos como fenómenos probabilísticos, não categoriais. Trata-se de estabelecer as estratégias que possam ajudar a compreender a complexidade transversal dos fenómenos tradutivos, a fim de oferecer aos ET um espaço metatradutivo. 0 objetivo é demonstrar que a aproximação a este campo tão complexo precisa de 
estratégias de pesquisa transdisciplinares, capazes de integrar tanto as ciências humanas quanto as naturais. Para além disto, este artigo supera a tradicional divisão entre ambas áreas científicas e incorpora modelos tais como a Terceira Cultura (Schrödinger 1951, Snow 1959 e Brockman 1996). Este estudo tenta assumir o desafio de prover os ET de uma epistémé (Nouss 1995), concebida como um laboratório mental que ponha em prática um conjunto de teorias diferentes, cada uma delas dotada de um limitado escopo de ação. Estas teorias comporão uma completa descrição das formas lógicas da função tradutológica na sociedade mediante a exploração da transdução dos fenómenos culturais nessa sociedade.

Palavras-chave: teoria da tradução, estudos de tradução, metanálise, função tradutológica, pesquisa transdisciplinar

Translation phenomena should not be regarded as categorical but as probabilistic. We may be tempted to think that the chances of a translation event happening depend on the number of ways in which it can take place, even though such chances may seem to be small (Mlodinow 2009). However, this is not a matter of calculation but rather of knowledge (Taleb 2008): whenever we have incomplete information about the causes, and such information is inevitable in the social contexts in which cultural phenomena occur, then in such cases, randomness plays a crucial role in their evolution, even though this does not mean that their characteristics are completely unpredictable (ibidem). Therefore, we cannot fully discard any kind of causation, bearing in mind that physical laws are a sound proof of its existence. Randomness and causal relationships do not exclude each other but are related concepts: there can be random noise in causal processes just like there can be a degree of causality in random processes (Bunge 2011: 19). Both are basic ways in which cultural phenomena, understood as translation phenomena, can take place.

First of all, any translatological gnoseology and epistemology ${ }^{1}$ that tries to configure a research field must refine its models and should incorporate the abovementioned aspects. Translation Studies (TS) must not only deal with the occurrence, consistency and evolution of cultural phenomena within the different specificities of social contexts but should also deal with everything conceivable in order to understand all its mechanisms and properties 
(Badiou 1999); a utopia because translation phenomena are problematic and are not known as knowledge objects.

What then are the strategies that can help us to understand the transversal complexity of translation phenomena? An initial first step would be to search for a reference criterion, in order to be able to configure the TS research field. This criterion might be that of function, partly following Luhmann's (1973) sociological theory. In gnoseological terms, function is a logical scheme which operates in the field of matter/form, with the aim of critically conceptualizing the different translation phenomena observed in society. It permits conversion of the TS research field into a process-based systematic totality, by developing function in its most diverse situations. This includes its transformation and even its denial or impossibility. Another feature derived from the above is the relationship between the gnoseological world of research (ideas, operations, relations, etc.) and the world of facts (Bueno 1993), in order to be able to fit the complex materiality of translation phenomena mentioned above. The suitability of dissociating but not separating gnoseology from epistemology (ibid.) lies in giving TS a metatranslation space which would permit one to question and enquire about the tools used to analyze facts and their field of research (Nouss 1995, Baltrusch 2007, Pérez Durán 2008 and Baltrusch/Pérez Durán 2010). Despite the abstract level introduced by metatranslation practice, it permits assessment and correction of ways to theorize our knowledge about the translatology phenomena. ${ }^{2}$ This uncertainty leads us to another important point of metatranslation work; namely, visualizing what does not work. Inaccuracies in research should not be considered as a failure since they indicate things that do not work. Marcus (2012) states that negative results are as important as positive results. What is sure though is that complexity and recursive strength of any social phenomenon requires gnoseological and epistemic foundations of TS to be "updated" and continuously reviewed.

From a practical point of view, function is an analytical instrument that focuses on problems. The goal is to avoid self-assertion of logics in certain disciplines that collect evidence to match the sense of their explanations. Thus, this gnoseology of (in)stability also includes extreme and unlikely things that do not conform to standard scenarios. This takes 
us to another possibility which leads to the concept of function; namely, the comparison between its different implementations in the several social contexts it might appear.

All these innumerable contexts develop mechanisms that are specific to the translatological function. Each of them can be treated as functional equivalents (Luhmann 1973) such that the ways in which the function takes place can be observed and analyzed. The observation of how replaceable and modifiable a translation phenomenon can be provides us with the possibility of glimpsing into its present momentary pause status. We can also do the opposite, i.e., observe its absence, evolution and potential. The following example might clarify this: a phenomenon $x$ evolves from a state of temporary sedimentation $a$ to another phenomenon $b$. The gnoseological and epistemological goal of TS would be to not only diagnose the nature of temporary sedimentation of points $a$ and $b$ but also to ignore the transition from $a$ to $b$. Both provisional stabilization and evolution are dialectically rooted within each other, in an irreducible paradoxical game that any contribution must preserve in its contradictory, ambiguous and heterogeneous strength. These features will be discussed in detail later. ${ }^{3}$

The assumption that function is one of the pillars of the complexity of the research field implies the handling of an enormous amount of information. It needs a variety of strategies that cannot be exclusively limited to human or natural sciences. Likewise, each of these theoretical strategies should not monopolize research but should be modeled within its limited scope of action, as will be clarified further below. Thus, the complexity of the research field, formulated from the idea of function, does not allow for a reductionist analysis linked to one or several theories. ${ }^{4}$ We therefore need to assume the presence of locally valid models in the different adscription strata which overlap and cause mismatches (Stewart 2001: 505-507). Hence, we do not need to know the elementary particles of physics to understand the interactions between people and society (ibid.).

Lastly, the use of these transdisciplinary research strategies calls for a balance between two basic needs: divergence and convergence (Bunge 2010: 11):

1. As stated earlier, the problems tackled by the TS research field are multidimensional 
in nature. Therefore, divergence between disciplines is needed to understand translation phenomena, not only in a specific but also in a heuristic manner (as explained below in point 2). It becomes a feedback loop, i.e., if the available information is part of a whole entity, then the addition of contributions from each discipline leads to an updating of knowledge with new statements and questions. ${ }^{5}$

2. However, the clash between the types of representation and the nomenclatures of the different disciplines warrants convergence at two complementary levels for TS to become a transdiscipline. ${ }^{6}$ On the one hand, we need to open an intersection to allow the creation of a non-idealist analytical space in order to erase limits between disciplines without neutralizing conflicts and internal contradictions. On the other hand, linking a great variety of disciplines requires a convergence related to epistemology and gnoseology (Bunge 2010). This need arises as a result of the search for a series of basic gnoseologic ideas (function, world, matter, reality, etc.) to link the divergent disciplines. This, together with the metatranslation practices described above, forms part of what we could call basic TS research, which would deal with its fundaments and its review. ${ }^{7}$ This basic research, rather than act as a group of consensual basic axioms, would serve as a tool to reach certain provisional axioms. Tools and axioms can always be improved and that is why they are always being adapted.

The ultimate challenge would be to provide TS with an epistémé (Nouss 1995). It would have to be conceived as a mental laboratory that puts into practice not a common theory but a family of different theories with a limited scope of action that provides a description of the different logical ways of the translatological function in society.

What then is the functional criterion needed to configure a research field in TS? The answer seems to be the transduction of cultural phenomena in society. This paper uses the terms 'transposition' (Genette 1989: 263-477, Griffiths et al. 2000 and Haydu 2002) and 'transduction'8 as synonyms (Dolezel 1986 and 1997, Griffiths et al. 2000 and Maestro 2002). Both concepts are wide enough to encompass all simultaneous processes of 
transmission, transformation and interaction of cultural phenomena, both oral and textual, including the sociocultural, semiotic, economic and mediation problems (Martín-Barbero 2010).

On the other hand, these two notions are free of any ideological baggage that burdens their meaning, as is the case with terms linked to globalization: hybridization, creolization, mixture, syncretism, melting pot, crossbreeds, etc. despite their describing very similar realities (Appadurai 1996, Burke 2010 and Pietersee 1995). The generalized and common use of these terms usually tends to forget the resistance, imposition and conflict $^{9}$ factors that are intrinsic to any social change, thereby disguising society from a diverse, ubiquitous and deterritorialized world (Friedman 1995 and Robertson 1995). Another important advantage of 'transposition' and 'transduction' as key concepts for describing the function that configures the TS research field would be the fact that they do not exclusively belong to any particular field, since they also have standardized functions in biology, neurology, logic, law, medicine, music, maths or (epi)genetics. According to the above idea of functional and transdiscipline equivalence, the adaptation of this terminology to TS would enable knowledge and description of other phenomena, regardless of their adscription to a single discipline.

The current circumstances need an action proposal (multiple-model approach) that really approaches the large amount of information that needs to be processed ${ }^{10}$ in this field of research and which tries to understand the translation phenomena. Handling translation materials according to the state of research also invalidates the dichotomous way of thinking (centre vs. periphery, original vs. imitation). However, one of the temptations that must be avoided when faced with the complexity of translation phenomena is that of resorting to making generalisations that disguise the translation phenomena with an alleged diversity that is lacking in such epistemic approaches. On the subject of knowledge transmission, it would be ideal to overcome the existing traditional division between natural and human sciences by using models such as the third culture articulated by Brockman (1996), from the ideas of Schrödinger (1951) and C.P. Snow (1959).

One of the tasks of TS as a transdiscipline would be to search, compare and understand the 
different contextual variables in which this functional criterion develops within sociocultural systems. Therefore, the translatological research field cannot refer to a single object or to something that can be considered a global and unitary entelechy. Quite to the contrary, TS should have multiple objects in order to build relationship networks, which will be determined via their operational processes. ${ }^{11}$ By definition, a translatological theory should be polycontextual, in accordance with a society conceived in a decentralized, conflictive and contradictory manner (Luhmann 1998).

To sum up, translation broadly needs to be resized into a basic function of sociocultural systems. This is because it is subject to governance and interaction between human beings and complex social systems, from the most elementary levels (neuronal, for example) to macro-social levels (self-organization of social systems or beliefs, among others), including its own emerging properties. ${ }^{12}$ From this point of view, it could acquire all the characteristics of a common, which is useful for the development of a future functional-hermeneutical model of sociocultural phenomena (Ostrom/Hess 2007 and Ostrom 2009). Such a model would be able to combine the individual and social knowledge mechanisms, in addition to the socioeconomic, political and biophysical contexts.

\section{Towards a transdisciplinary mapping of the TS research field}

In 1990, when Bassnett and Lefevere proposed a "cultural turn in Translation Studies" demanding that translated texts be analyzed "embedded in their network of both source and target cultural signs" (1990: 10), there had long existed the pressing need to insert the conception of translation, and not just textual translation, in multiple contextual dynamics. ${ }^{13}$ Nowadays it is commonly accepted that translation depends on sociocultural evolutions. ${ }^{14}$ A more linguistic or cultural and social vision of translation is perfectly compatible, since we would be dealing with different levels and goals of translation phenomena. However, integrating them into a holistic and complex conception is one of the theoretical challenges for the research field of TS.

In fact, the integration of the cultural dimension focuses on the transformation of cultural phenomena and their communication within society. Therefore, we would also 
need to map their complexity by not only connecting the big structures but also the smallest dimensions: individuals, cognitive structures, etc., together with the unavoidable appearance of new blank spaces.

However, the introduction of the cultural parameter took the academic discourse to such a level of abstraction and rhetorical use that any trace of subordination, social differences, dominance, etc. was almost eliminated from its analysis. Thus, as Buden (2006) points out, it is not the case that the notion of culture offset the notion of society in theoretical discussions and political practice, but that the cultural scenario became the only one to mediate in the perception of political reality (Moreiras 2007) and hides any possibility of seeking social justice, equality etc. as "culturally determined" (Buden 2006).

The culturalization of social elements is a danger that TS must avoid. Translation plays a key role in unravelling the discourse of essentialist plurality of multi-culturalism and the deconstruction of the narrative that comprises any cultural implementation. It therefore helps to understand, intervene and subvert the binary antagonisms that characterize modern politics (Buden 2006). An attempt to propose a separate social turn or a cultural turn in TS is quite disconcerting because thinking of culture outside society and not as its implementation (Luhmann 1998) is a fallacy. It would be more appropriate to speak of a sociocultural turn if we want to insist on the change of perspective observed in the last few years, according to the concept of 'common' suggested at the beginning of this paper (Hess/Ostrom 2007, Ostrom/Hess 2007 and Ostrom 2009). On the subject of culturalization of social elements, the main thing is to explore the interaction between what is cultural and social, instead of analyzing representations of the political, economic and social elements in the cultural framework (Sennett apud Bilbao/Hax 2012). As suggested by Talcott Parsons (1999), the function of cultural systems is to act as classifying templates which must be maintained and transmitted, even if they are not used instantly, within the social action of individuals and social groups. Thus, translation plays a crucial role in the evolution, selection and variation of culture, by acting as a (non-)hereditary memory of the community (Aunger 2004 and Lotman et alli 1979).

Nowadays, it is quite common to perceive cultural systems as permeable, mixed and 
crossbred: They are complex systems for relation and replication of transcultural and intracultural information. Transcultural and intra-cultural dynamics could be defined as two phases of the import and transfer process of cultural elements, which are dialectally related and in continuous co-evolution (Sassen 2007):

1. The transcultural phase would correspond to the period of import and adaptation in the target cultural space. Haiku in European modernism is a good example wherein a poetic genre with a thousand-year-old heritage in Japan becomes representative of modernity and avant-garde in Europe and America (Walsh Hokenson 2007). However, the continuous destabilization of cultural systems due to rapid creation of new assemblies makes this phase much more active in societies affected by globalization (Sassen 2010: 474-475). Globalization processes took intrinsic features from any given society to the next level (change and relationships, exchanges and expansion of any type of elements). Global cities (like New York, Buenos Aires, Paris, etc.) might certainly be the most obvious examples of these transductive processes related to globalization (ibid.).

2. An intra-cultural phase would be a complex network of relations between the transferred element and the receiving society, especially the power relations, the processes of dissemination, adaptation, resistance and re-combination with other sociocultural phenomena of the target society. It is not a final phase, but a temporary sedimentation that takes place in a specific space and can simultaneously occur with another implementation in a different place. This temporary fixation (Luhmann 2006: 97-120) contains a contraction of structures which have been gathered and reflected in different social ways. Therefore, it has internal insoluble conflicts between the accumulation of implementation possibilities and the resolutions temporarily reflected within a specific social context. However, the fixation operations of those facts can be repeated and therefore create a double effect (ibid.). On the one hand, in order to reproduce a specific event, it must be identified with a sense, carried out and communicated by a person and/or social group, which will 
single it out from the rest. On the other hand, in such a fluctuating and fragmentary context, such as the social dimension, it produces an effect of continuous learning (cf. Kauffman 2003 and Mühlmann 1996). Therefore, from that moment on, the concepts of fixation or temporary sedimentation designate the generation of long-term structures in the process of ongoing self-organization and self-poiesis of sociocultural systems (Luhmann 2006: 97-120). These structures are monitored by time-space variables, which configure a specific transitory 'historical present' (Benjamin 1992) with their own 'language games' (Wittgenstein 1998) and emerging phenomena. At the same time, the changes in any social or cultural phenomenon from one historical present to another lie in their capacity of (un)translatability (Benjamin 2007).

Therefore, basing an epistemology of TS in binary questions would be simplifying and obsolete (Sela-Sheffy 2000). It may seem as though the processes of invention, import, ${ }^{15}$ imitation and transformation in a society are acting as a self-catalyst to promote the emergence of sociocultural phenomena (Diamond 1997: 239-263). However, just analyzing the transition of the transferred elements until they are well rooted into the target society is not enough, since the very nature of transition is in constant expansion, without purpose or end. Therefore, one needs to observe how transpositions are maintained, how they disappear or recombine, by taking into account a variety of factors with unforeseeable consequences. Abandonment, for example, can sometimes occur after a culture has incorporated a new element, for motives unrelated to the phenomenon or artifact itself.

These questions are intrinsically related to the problem of diachrony and synchrony of imported cultural phenomena, because the time-space axis and the flow of information/communication are key to understanding the transduction of this type of phenomena. A cultural phenomenon, whether or not imported/stabilized, is subject to evolutionary processes and changes. The important thing is its evolutionary rate and how it 
is assumed/assimilated or rejected by people, social groups and collective trends of a specific society within a specific time frame.

The physicist Richard Feynman hit the mark when he said that equilibrium happens when the fast processes have already occurred, but the slow ones are yet to occur (apud Kauffman 2003: 197). As Mühlmann points out (1996), the lack of knowledge about the most delayed cultural dynamics results in our fossilizing them by conferring relevance to them. That ignorance of the slow, according to Mühlmann, is due to the fact that observing the slowest transductive processes would require the collaboration of several human generations, which would be precarious because of the lengthy communications processes and the huge volume of information generated. As knowledge progressed, this territory of the unobservable (and disguised as relevant) changed from being a space reserved for divine and theological issues, to being a space where one can talk about the behaviour of long-haul events via models taken from the theory of complexity and self-organization, among others, either systemic or evolutionary (ibid.).

Consequently, the rate of evolution (together with time-space diachrony-synchrony) is one of the key problems also characterizing the TS research field. Therefore, the treatment of the different possibilities in which the transpositions of cultural phenomena develop in social systems should not be formulated in terms of opposition of essentialism vs. non-essentialism, determination vs. imprecision, etc. The nature of 'materiality' of cultural phenomena, and of its operations and processes precisely requires us to be aware that its main features are instability and a state of constant evolution and expansion, but without any goal. We must understand that the adscription of any cultural phenomenon to a specific form is never an indication of an imperturbable solidity but a proof that cultural phenomena are characterized by their allostasis, i.e., by keeping their stability through change (Sapolsky 2008: 30-32). ${ }^{16}$ As stated above, this allostatic capacity implies that adaptation mechanisms are started until a new equilibrium is reached in response to the continuous changes in the cultural transduction process. There are always variable conditions that force a continuous adaptation until a stability is achieved, which will never be permanent. This continuous friction can actually be framed within three factors: (i) 
variation/selection, (ii) transmission/dissemination and (iii) sedimentation (temporary) (Luhmann 1998).

When trying to define TS, the first decision that must be taken will have to be epistemological and gnoseological, i.e., is TS characterized by having its own field of research or is it an object of study? The answer would clearly be that the immensity of information gathered can only be handled and organized after establishing a field of research. This reaction is due to the difficulties experienced in distinguishing between the object of study and the cognoscent subject that analyses it. However, this clear distinction is quite difficult to establish because the cognoscent subject (and observer) usually projects its own prejudices towards the object of study.

The possibility of avoiding the subject/object problem lies in configuring a field of research around a function, which in the case of TS would be the transduction or transposition of socio-cultural phenomena, as defined in the first pages of this article. According to this theoretical framework, TS cannot be related to an unchangeable study object. For our approach to systematization of the epistemological foundations of TS, Bueno offers an essential complement in his general theory of science (1992: 117): no discipline must refer to an object (or something considered global and unitary, no matter how complex it is) but must be related to multiple objects in order to build a network of relations. The field of research should contain formal and material parts, with multiple terms determined via their operational processes (ibid.). And this is why the functional criterion was chosen.

Another consequence of these epistemic options, together with the transdisciplinary character (cf. Wilss 1999), is the abovementioned amount of information that must be dealt with. It would not make sense to defend TS as a purely linguistic, cultural or social discipline. The disciplines do not exclude each other and are perfectly compatible, be they CAT, community interpreting, audiovisual translation, adaptation, technical translation, localization or cultural translation, etc. It is true that each subdiscipline has its own specificities and operations, but their common element is the function that configures the field of research of TS; namely, the transduction of sociocultural phenomena. 
Translation and, by extension, TS, are already being used as fundamental pieces to understand contemporary societies. Translation has been studied as a form of social activism (Tymoczko 2000), political action (Schäffner 2007), or as key dynamics in multilingual societies - materialized as interpretation in public services, integration policies, etc. (which also happens in global cities, Sassen 2010). They have become a space of complex confrontation between the localization of the logics of standardization of globalization (economic, social, cultural, etc.) within a specific territory and its own specificities. This gives rise to acculturalization processes and/or new formats of resistance that either benefit or not from the globalization devices (Klein 2005). Thus, the theoretical and practical potential of translation (or TS) could play a main role in research in even more fields. ${ }^{17}$

Now that we have established the role of TS, what then would be its possible definition proposal? With the provisional reserves of a research in progress, TS could then be considered a transdiscipline whose field of research is comprised of allostatic dynamics and the transposition of cultural phenomena within the dynamics of a theoretical-practical reason (cf. supra). It would encompass the study of operations that affect all kinds of translation processes - from cultural translation to oral and textual translation, in general, and its specific applicability in mediation (i.e. transmediality) and problem solving in multicultural societies, to name just a few- within the complex systems they belong to (naturally conditioned by aspects such as cognition, randomness, creativity, social imagery, political structures, economical structures, biogeographical, etc.).

Thus, a first and important task would already be taken care of, i.e., differentiation from the other fields of research and establishment of a functional criterion, which is the starting point of any research work. Difficulties arise later with the need for dealing with the huge amount of information involved in the transposition of any cultural product. Moreover, activism and intervention are also essential components as TS is not just a simple exercise of abstraction. Besides the ethical implications, there is still the need for communicating and spreading the theoretical conceptualizations of TS in order to ensure 
that they remain not just restricted to the academic world but that they can receive an ongoing feedback in theory and practice. ${ }^{18}$

\section{The problem of turns when marking the evolution of the research field of TS}

When facing the complexity of the TS research field, there is a paradox: the form in which each state of things is presented has two versions, namely, unit and multiplicity. However, there are keywords that are commonly used to conceptualize both states, without doing much more than pointing out truisms about TS: the proliferation of tags such as cultural mediation, hybridization, cultural diversity, negotiation, transcultural communication, third spaces, multisemiotic aspects, border thinking, etc., reveal that in sociocultural aspects, 'normality' means change. The problem arises when we take the next step. Just because we name concepts, we do not have an epistemology nor solve most challenges associated with such concepts. There are still many unanswered questions: what is the territory in which translation phenomena are developed and self-organized? What shall we do with relations of subordination, social differences or domination? How can we introduce the parameters of randomness in the epistemological construction of TS?

Translation Studies have always been carried out in separate sectors except for a few special cases. With this, I am not supporting the dissolution of the specificities of each discipline. However, the TS research field is an extreme case, in which the simultaneous nature and complexity of translation phenomena is often not just a linguistic or an ideological or cultural issue. Therefore, sorting all subject matter from the TS research field into categories and displaying them in separate showcases does not match the way they exist in the world. The challenge of TS is that of accessing all variables experienced by translation phenomena in sociocultural reality according to the above-mentioned idea of function. There is really a lack of a theory of knowledge suitable to the TS research field that is subject to the (non)linear, (a)symmetrical, autopoietic, self-organized, self-referring and recursive logics of cultural phenomena which does not reproduce past epistemological inertias. Likewise, this theory must be able to remain permeable, without getting stuck in a text dependence or distance itself from activism and ethical commitment, for example. This 
is not an original addition and simply means going back to the old issues but with new tools. We therefore should not keep on theorizing the process of acquisition of translation rules and practices or the decision-making of the translator without taking into account the cognitive function of human beings or having a reductionist conception of human reason. For this, we need a systemic approach (Bertalanffy 1976) of TS, which combines scientific realism (Mahner 2001) and emergentist materialism (Bunge 2010).

Therefore, describing the evolution of translation theory as paradigmatic turns (following Feyerabend 1986 or Kuhn 2004) ${ }^{19}$ does not seem to be a productive exercise. If we set aside the inflationary use of the unclear concept of paradigm, then Kuhn's statement (2004) that scientific research is linked to social influences and scientific communities begins to gain relevance. However, Kuhn's theory of paradigms also gives rise to at least four problematic fields (Masterman 1999: 59-90):

(i) comparing theories is almost impossible,

(ii) a paradigm can be identified with a 'mental prison' (supported by a conceptual network that interprets reality),

(iii) a paradigm implies a restrictive conception of rationality (which excludes the unconscious and the emotions and feelings from decision-making and reasoning),

(iv) it is impossible to specify the exact moment of change from one 'paradigm' to another and the very concept of paradigm is inconsistent (ibidem).

The identification of scientific paradigm with a mental prison suggests the idea that it is a completely closed framework, with a capacity to absorb any anomaly or discrepancy that questions its postulates. Thus, there is a transfer of methods and operations between paradigms which contradicts the total closure hinted by comparison. On the contrary, the discovery of inconsistencies permits restructuring and correction of data and hypotheses put forward not because there is a social consensus but because the theories and hypotheses are either true or false - in the sense of truth, as a synthetic identity (Bueno 1992)..$^{20}$

Another doubtful aspect of Kuhn's ideas is the incommensurability of his theories. 
On the one hand, this gave rise to a way of understanding scientific research from an evolutionary perspective, albeit without believing in the utopia that knowledge accumulates and gradually evolves (Kuhn 2004: 241-261). And, on the other hand, it created confusion between 'rival' theories and the lack of capacity to compare theories. In order to be able to compare two theories in a reliable manner, both must share the same reference and sense. Behavioural psychology and Jauß's reception theory, for instance, are not comparable and do not share a common domain. However, when theories occupy the same set of references and senses, then they become comparable and rival since they represent different interpretations that try to explain the same set of events. In this sense, Planck (1936: 97) ironically stated that one theory triumphs over its competing theories not because it convinces detractors but because detractors end up dying, and therefore a new generation grows up and gets used to the new theory.

However, the biggest difficulty faced within the perspective of paradigmatic changes is this supposed change from one paradigm to another. How, when and what are the reasons for this change? If we apply this to the field of TS, we notice an almost equivalent use between paradigm and turn (cf. Bachmann-Medick 2009, Bassnett 1998, Bassnett/Lefevere 1990 and Snell-Hornby 2010). We need to ask ourselves whether this perspective is really effective or if it represents an obstacle that makes us see the different translation theories as different showcases, with their own network of concepts and epistemology. The analysis of changes ascribed to the turns in the theory of TS in the last decades permits the observation that these are attempts at introducing new variables within an already accepted coordinate system. The appearance of 'cultural', 'social' or even 'sociocultural' variables means the introduction of new terms within already established relationships and operations. Thus arises a need to re-interpret the variables by taking the new parameter into account. Rather than consider turns in translation studies as paradigms, we need to adapt their internal structure in order to acknowledge the new item in accordance with a set of new calculations. However, this does not mean that we should consider each variable introduced by a turn as a change of paradigm. Analogically, it would be similar to the fracture caused by Einstein and quantum physics with respect to 
Newtonian physics, where the linguistic turn would become a cultural turn, or an ideological turn (Wing-Kwong 2006), or a translational turn (Bachmann-Medick 2009), etc. in a translatological theory context.

In this sense, the theoretical discourse of turns in TS gives a false image of epistemological and gnoseological rupture even though there is none whatsoever. It also leaves out the baseline research, as stated above. What then would be a possible solution to start building multipurpose foundations for a theory of TS? If we consider that a complete and definite transdiscipline is utopic, then at an epistemological and gnoseological level TS has to accept a series of ontological and transversal ideas which, together with the metatranslation consideration, become part of its baseline research. This ontology of concepts would have to be adapted to the need for ongoing change of the TS research field materials and some problems derived from it, such as diachrony-synchrony, distinction between subject-object and the point of observation.

An approximation to a theory of TS would only be viable if we consider a network of effective theories, which are linked by a series of basic ontological and transversal ideas causality, reality, world, matter, etc. We should not forget that the function would be the main point within which the research field is configured. The basic idea of elective theories is that each of them models a few phenomena within its scope of action, without the need to fully describe the underlying processes (Hartmann 2001 and Hawking/Mlodinow 2010). We could consider that each model has a validity that is limited to a context and thus, the use of a functionalist perspective —as established by Nord (1997), Oksaar (1995), Reiss/Vermeer (1996) and Vermeer (1983)—, would be compatible with descriptivist theories (e.g. Toury 1995), as long as they maintained the basic coherence and cohesion when understanding the ontology of the materiality being analyzed. This allows "[to] use a plurality of interrelated conceptual tools, and explanations [that] are obtained by attacking a phenomenon from a variety of theoretical perspectives. It is this pluralism of tools which is good for science and which makes science flourish" (Hartmann 2001: 39). The goal of formulating a combination of effective theories would lack the nostalgia of consensus (Holmes 1988: 67-68) and the supposed uniqueness of TS (Baker 1996). 
As a complement to the concept of effective theories, the approach of Merton's middle-range theories (2002) is another useful toolbox to elucidate the multi-level complexity of TS and its category as a transdiscipline. The presence of transdisciplinary fields of research must stop being an exception because change can be considered a norm within TS. To a great extent, Merton thought that within the network of general theories, i.e., those that try to explain a great deal of phenomena but are not specific enough due to their nature, there is enough elasticity and overlap for more specific theories (those researching small groups of phenomena and not trying to explain all phenomena) to be integrated within the network of general theories, even though they may clash with each other. Therefore, according to the ideas of polycontextual society, function and functional equivalent shown before, the relationship between general and middle-range theories allows for those abstract and general aspects to be in contact with the particular data and specificities of each analyzed context.

Both the concept of effective theories and Merton's ideas shape transdiscipline. They break the dichotomy between micro-level and macro-level perspectives and furthermore deactivate the reductionism or general theory duo in the light of the complexity of translation phenomena. Therefore, they allow for coherence with the organic, (non-)linear, (a)symmetrical, autopoietic, self-organized, self-referring and recursive aspects and the problems of diachrony-synchrony and time-space of cultural phenomena with regard to being considered as translative.

\section{Conclusions: TS as a transdiscipline}

As already stated above, the introduction of the concept of function and the definition of the field of TS derived from it must be flexible enough to prevent the cancellation of any divergence by integrating postulates. The starting point behind this is that any attempt at thinking and analyzing social phenomena, in general, and cultural phenomena, in particular, should be preceded by complexity. This is because society is not just a multiplicity of individuals. However, there needs to be enough cohesion for the TS research field to differ from others. Thus, there arises a need to adopt a transdisciplinary 
perspective when stressing function. On the one hand, this will try to explain cultural phenomena as translational events and, on the other hand, it will allow a systemic perspective to operate as a driving force at the gnoseological and epistemological level. Therefore, TS as a transdiscipline connects two forces, which were traditionally thought to be conflicting, i.e., the spread of points of view whose common feature is the transduction of cultural phenomena and the convergence at gnoseological and epistemological level. It thus acts as a foundation for establishing a precise image of the research field, and introduces the idea of an ongoing reflection that analyzes and enhances research methods and practices. In this line, the flexibility of the approach of effective and middle-range theories strengthens the interaction between the specific aspect - the performance of the translatological function, and the general aspect, an epistemic and gnoseological network (causality, reality, world, matter, etc.) which weaves the different effective theories that configure the research field of TS.

Even though we have stressed that gnoseology of TS must be a "unity in diversity" (Bowker et al. 1998), a "difference in diversity" (Bassnett 1999) or "a house with many rooms" (Neubert/Shreve 1994), we still have to confer a context for these intentions: how then do we achieve that "multiple-model approach" (Gentzler 2001: 163)? How can we stop it from being a rhetorical idea stuck in idealism so that it is viable and useful? The paradox is that, on the one hand, an attempt is made towards establishing cooperation between disciplines that enrich TS but, on the other hand, we continue to work with descriptive parameters that follow old logical-ontological traditions.

Whether it is for good or bad, TS mainly analyzes the transposition of cultural phenomena. At a basic research level, we must deal with organic, (non)linear, (a)symmetrical, self-organized, self-referring and recursive aspects and the problems of diachrony-synchrony and time-space of these phenomena. When we focus on complexity to delimit the research field of TS, we avoid general explanations that are stuck in a false timespace invariance (Gould 2007: 1339-1341). Therefore, this paper proposes that TS be based on the idea of function, on the effective theories, on the systemic perspective and on the 
idea of transdiscipline. However, the huge amount of information that needs to be processed in this task requires special intellectual modesty.

Perhaps the biggest setback is that basic research in TS dealing with elementary epistemic conceptions - reality, world, matter, causality, etc. - has not yet been carried out rigorously. The definitions and respective distinctions would have transversal effects but are essential in order to lay the foundations for effective TS theories. To that end, we need to develop aspects such as the ontology of concepts and ideas, tackle the diachronysynchrony problem, overcome the subject-object difficulties, and question the cognoscent subject, self-referencing, randomness, uncertainty, complexity networks, etc.

These epistemic and transversal links do not conceive translation as a 'harmonized whole'. Their operational ability comes from the specific problems presented by translatological phenomena. The option of transversality implies the introduction of a complexity that must be managed with a logical-ontological base according to the requirements of the 'materiality' of cultural phenomena. For example, we should not elaborate a template of decisions made in lexical choices without considering what cognitive sciences or game theory can add to the matter. This takes us back to the starting point: problems, and not the most comfortable tools, should determine research for the observer.

Transdisciplinarity is yet another consequence of this set of epistemic choices. Such non-adscription to a specific school or theory could bring along a number of tools that would complement the understanding of translation phenomena. However, this creates a bigger difficulty when organizing the different perspectives provided by each tool. However, the combination of different perspectives and scientific traditions will surely generate further questions, since research is an end in itself. TS, anthropology and cultural neuroscience 21 for example, "can aid the development of theoretical approaches to embodiment that more richly help describe the processes and consequences of emotion socialization, throw light on the cultural processes that affect the symptom presentation" (Seligman/Brown 2010: 137).

Regarding this, Rule et al (2013: 8) state that "cultural neuroscience is in an even 
greater position to bridge the culture-biology gap by drawing together perspectives and methodologies from every area of psychology (e.g., cognitive, social, and developmental), as well as from the fields of anthropology, molecular biology, and neuroscience". We would like to add that feedback with TS would permit one to see differently, both in relation to some research problems in cognitive, as well as in social sciences regarding the interactions between individuals, social groups or society as a whole. According to what has already been said about the constellation of effective theories combined with Merton's epistemic ideas, many problems that TS tries to solve are fortunately also researched by other disciplines, either directly or indirectly. The gap created by such problems provides an opportunity to establish connections between disciplines that deal with the common problem. Therefore, TS can be a starting point from humanities to provide content (at all levels) to the intentions of the third culture in overcoming the traditional division between natural and human sciences (Brockman 1996).

The challenge therefore is to turn TS into an episteme (Nouss 1995) that does not only create an interpretation system but also promotes a self-critical capacity. To illustrate this, we want to remember a little story. When once asked about improvisation, Miles Davis mentioned an attitude of exploration that should also be applied to TS: "almost like an invitation, a challenge to go forward into something I knew nothing about" (apud Kahn 2000). This is, precisely, the current challenge of TS: preventing time from crippling its capacity for innovation and creativity. 


\section{NOTES}

${ }^{1}$ I will apply the distinction made by Gustavo Bueno (1992 and 1993). The difference is that epistemology would be the theory of knowledge, either mundane or (pre-)scientific, organized around the cognoscent subject/object opposition, while gnoseology would be structured in relation to the form/matter distinction (ibid.). We must be careful with the issues of form/matter due to the constant rearrangement between ontology, epistemology/gnoseology and the frames of reference in the TS research field. This is because contingency in social phenomena, understood as translative, also comes from the existence of an autonomous outer world oblivious to the human brain, which is always limited by its own neurological system and by the subjectivity it confers upon what is observed. Therefore, social phenomena, in general, and translative phenomena, in particular, emerge as a result of the combination of a human brain and the autonomous action it perceives (Bunge 2010).

2 Meta-analytical practices are also useful in other sciences, such as social psychology (cf. Armitage/Conner 2001), medicine (The Cochrane Collaboration [http://www.cochrane.org]) or social sciences (Berger 2013). This importance results in the need to systematize studies that prove nothing on their own.

${ }^{3}$ Cf. 'in-between' (Tymoczko 2000 and Wolf 2000), 'act' and 'strength in Aristotle' (Peña García 1984), the 'to be instead of not to be' by Deleuze (Pardo 2011), the 'constellation' or 'dialectic image' by Walter Benjamin (Benjamin 2005 and Kampff Lages 2007) and 'texte traductif' (Nouss 1995).

${ }^{4}$ The concept of 'complexity' is used in the sense established by Barabási (2003: 6-8) and Stewart (2001: 7980 and 475-507).

${ }^{5}$ In the light of the logic of Gödel's theorems of incompleteness and the platonic simploké (Bueno 1993), we could ask ourselves: when is a transdiscipline consistent enough so that it does not need a systemic integration of certain aspects from other disciplines? Or, on the contrary, since the combination of known elements that take us to the unknown seems to be infinite, will a transdiscipline never be fully completed?

${ }^{6} \mathrm{Cf}$. the concept of transdisciplinarity in Bachmann-Medick (2009: 2).

7 Therefore, elementary research, as part of metatranslative research, is critical to the development of the transdisciplinary translatological field and is also a source of unavoidable conflicts (cf. Paletz, Schunn / Kim 2013 and Dunbar 1995).

8 This concept is useful in TS, cf. Silverstein (2007) and Tymoczko (2000).

${ }^{9}$ One of the relations to be explored and systematized in TS is the link between conflict and the processes of transposition of sociocultural phenomena, for example the perception of 'strange/foreign elements' in the different societies all over the world (cf. Das 2002 and Mona Baker 2006). 
${ }^{10}$ We should try to use the data mine crowd in the future for an easier observation of patterns in reality and thus partly decrease the huge amount of information that must be analyzed in the TS research field.

11 For other applications of Niklas Luhmann's sociological theory in translation studies, cf. Hermans (1999) and Tyulenev (2009, 2010 e 2011).

12 When using 'emerge' and its noun 'emergence' or 'emerging property', I am referring to the main property of complex systems, dealt with by the sciences of self-organization, complexity and cybernetics (Johnson 2002). On researching the role of self-organization and randomness in social systems and the emergence of social phenomena see Camazine, Deneubourg et al. 2001 and Solé 2009. They are useful tools to observe how the dynamics of stabilization and conflict, diffusion and contagion, the intricate relationship with individual cognition and the configuration of social imagery, etc. work within society.

${ }^{13}$ When we use tags or any other way of pigeonholing reality, a false sense of novelty is often projected. Before Bassnett and Lefevere the cultural turn started to be applied, for example, in the 1950s and 1960s in Brazil in line with concrete poetry and the theory of anthropophagy and translation (cf. Campos 1992). And in 1981, Even-Zohar already spoke of the need to equate the notions of transfer and translation process, once again highlighting the sociocultural context, as well as trying to avoid the exclusive identification between translation and text: "In transfer/translation, the transfer principle will be taken as a procedure, which due to the decomposition/recomposition unavoidably involved in it, processes the utterances/texts so they behave differently from the source" (ibid.: 7). On the other hand, in the 1980s, the functionalist approaches in translation already started to work on the concept 'cultureme', which deals with the question of culture in texts and how it is transferred to the target text (Nord 1997, Oksaar 1995 and Vermeer 1983). And as a last example of background, in the 1990s, Alexis Nouss (1995), following the hermeneutical tradition of translatological thought, proposed to adopt the paradigmatic novelty of translation as epistémé of our modern contemporanity. In line with Nouss, but with different nuances, Bachmann-Medick proposes that a "third stage in the «translational turn» might be to harness the characteristic self-reflexivity of the translation category to help us consider our own research in the analysis of culture as itself a task of translation humanities as a kind of «translation studies»-" (2009: 11-14). On these different proposals of paradigmatic changes in TS, cf. Snell-Hornby (2010).

${ }^{14}$ However, I do not intend to define my position within a sociology of translation (cf. Wolf 2007 and Wolf / Fukari 2007) but rather to advocate for a systemic model (Bertalanffy 1976), which combines scientific realism (Mahner 2001) and emergentist materialism (Bunge 2010).

15 The dynamics of innovation/import/adaptation in the process of creation of cultural repertoires (EvenZohar 1981 and 1997) might be from other places and times. However, in the present day, where this process 
is getting faster, the fact of having lots of past-time information does not necessarily reflect the context in which it was generated (Reynolds 2011).

${ }^{16}$ For the application of allostatis in the understanding of translative dynamics, cf. Perez Durán (2008), Baltrusch / Pérez Durán (2010).

17 These aspects might even offer new models of work organization, transnational companies, international protocols and trade relations, marketing and localization in relation to its selling capacity, diversity (ibid.), etc.

${ }^{18}$ As reflecting on practice improves the role of theory and the other way round (Vidal Claramonte 1998: 120).

19 There are other concepts that have a very similar referentiality, such as "thought styles" (Fleck 1986) and "research programme" (Lakatos 1981).

${ }^{20}$ According to this idea of truth, the concept of function and effective theory is related to this perspective of Bueno (1992 e 1993), since it limits the action of truth to a specific range or reality.

21 "In our view, cultural neuroscience is an interdisciplinary field that researches interrelations among culture, mind and the brain" (Kitayama/Park 2010: 112). 


\section{Bibliography}

Appadurai, A. (1996), Modernity at Large. Cultural Dimensions of Globalization, Minneapolis, University Minnesota Press.

Aunger, R. (2004), El meme eléctrico. Una nueva teoría sobre cómo pensamos, translated by J. Ros, Barcelona, Paidós.

Badiou, A. (1999), El Ser y el Acontecimiento, translated by R.J. Cerdeiras / A.A. Cerletti, Buenos Aires: Manantial.

Baltrusch, B. (2007), “Teoria e prática da Tradução \& Paratradução de literaturas e culturas contemporâneas", À Beira 6, 11-53.

-- / G. Pérez Durán (2010), “Na orografía do mudable. Cara a uns Estudos de Tradución \& Paratradución", in Soldando Sal. Galician Studies in Translation and Paratranslation, by eds. B. Baltrusch / G. Pérez Durán / K. Sartingen, 9-33, Munich: Martin Meidenbauer Verlag.

Bachmann-Medick, D. (2009), “Introduction. The Translation Turn”, Translation Studies 2:1, $2-16$.

Baker, M. (1996), "Linguistics and Cultural Studies: Complementary or Competing Paradigms in Translation Studies?, in A. Lauer et al., Übersetzungswissenschaft im Umbrach. Festschrift für Wolfram Wills zum 70, Tübingen, Gunter Narr Verlag, 9-19.

Barabási, A-L. (2003). Linked. How Everything is Connected to Everything Else and What It Means for Business, Science, and Everyday Life, New York, Plume.

Bassnett, S. / A. Lefevere (eds.) (1990), Translation, History and Culture, London, Pinter.

Bassnett, S. (1998), “The Translation Turn in Cultural Studies”, in Constructing Cultures. Essays on Literary Translation, by eds. S. Bassnett / A. Lefevere, 123-140, Clevedon, Multilingual Matters.

-- (1999), “Translation 2000. Difference and Diversity”, Textus 12/2, 213-218.

Benjamin, W. (1992), Sobre Arte, Técnica, Linguagem e Política, translated by Ma Luz Moita / 
MaA. Cruz / M. Alberto, Lisboa, Relógio d’Agua.

-- (2007), “'A tarefa de quen traduce' von de Walter Benjamin”, translated by B. Baltrusch / S. Montero Küpper / X.M. Garrido Vilariño, Viceversa 13, 79-103.

Bertalanffy, L. von (1976), Teoría general de los sistemas. Fundamentos, desarrollo, aplicaciones, translated by J. Almela, México, Fondo de Cultura Económica.

Bilbao, H. / A. Hax (2012), "Richard Sennett: 'Hay que perder el miedo al fracaso'”, Clarín (27.07.2012), <http://www.revistaenie.clarin.com/ideas/Richard-Sennett-entrevistasociologia-buenos-aires_0_745125489.html> (viewed on: 01.08.2012).

Bowker, L. / M. Cronin / D. Kenny / J. Pearson (eds.) (1998), Unity in Diversity? Current Trends in Translation Studies, Manchester, St. Jerome.

Brockman, J. (1996), "Introducción. La tercera cultura que emerge”, In La tercera cultura. Más allá de la revolución científica, by ed. J. Brockman, 13-26, translated by A. García, Barcelona, Tusquets.

Buden, B. (2005), "The Pit of Babel or: The Society that Mistook Culture for Politics", Transversal/ eipcp, translated by A. Derieg, Wien, European Institute for Progressive Cultural Policies, <http://translate.eipcp.net/strands/01/buden-strands01en> (viewed on: 03.02.2011).

-- (2006), "Cultural Translation: Why It is Important and Where to Start With It", Transversal/ eipcp. Wien: European Institute for Progressive Cultural Policies, <http://translate.eipcp.net/transversal/0606/buden/en> (viewed on: 03.02.2011).

Bueno, G. (1992), Teoría del cierre categorial. Introducción general. Siete enfoques en el estudio de la ciencia, vol. i, Oviedo, Pentalfa.

-- (1993), Teoría del cierre categorial, vol. II, Oviedo, Pentalfa.

Bunge, M. (2010), Matter and Mind. Philosophical Inquiry, Boston, Springer.

-- (2011), 100 ideas. El libro para pensar y discutir en el café, Buenos Aires, Editorial Sudamericana. 
Burke, P. (2010), Hibridismo cultural, translated by S. Chaparro Martínez, Madrid, Akal.

Camazine, S. / J-L. Deneubourg, N.R. / Franks, J. Sneyd / G. Theraulaz / E. Bonabeau (2001), Self-Organization in Biological Systems, Princeton, Princeton University Press.

Campos, H. de (1992), "Da tradução como criação e como crítica", in H. de Campos, Metalinguagem \& Outras Metas, São Paulo, Perspectiva, 31-48.

Chesterman, A. / R. Arrojo (2000), "Shared Ground in Translation Studies", Target 12:1, 151-160.

Das, V. (2002), “Violence and Translation”, Anthropological Quarterly 75:1, 105-112.

Diamond, J. (1997), Guns, Germs, and Steel. The Fates of Human Societies, New York, W.W. Norton.

Dolezel, L. (1986), “Semiotics of Literary Communication”, Strumenti Critici 50, 5-48.

-- (1997), Historia breve de la poética, translated by L. Alburquerque, Madrid, Síntesis.

Even-Zohar, I. (1981), “Translation Theory Today. A Call for Transfer Theory”, Poetics Today $2: 4,1-7$.

-- (1997), “The Making of Culture Repertoire and the Role of Transfer", Target 9:2, 373-381.

Feyerabend, P.K. (1986), Tratado contra el método. Esquema de una teoría anarquista del conocimiento, translated by D. Ribes, Madrid, Tecnos.

Fleck, L. (1986), La génesis y el desarrollo de un hecho científico, translated by L. Meana / A. González de Pablo, Madrid, Alianza.

Friedman, J. (1995), "Global System, Globalization and the Parameters of Modernity", in M. Featherstone / S. Lash / R. Robertson, Global Modernities, London, Sage, 69-90.

Genette, G. (1989), Palimpsestos. La literatura en segundo grado, translated by C. Fernández Prieto, Madrid, Taurus.

Gentzler, E. (2001), “Expanding Horizons or Limiting Growth?”, Target 13:1, 160-165.

Gould, S.J. (2007), La estructura de la teoría de la evolución, translated by A. García Leal, 
Barcelona, Tusquets.

Griffiths, A. J.F. / J.H. Miller / D.T. Suzuki / R.C. Lewontin / W.M. Gelbart (2000), An Introduction to Genetic Analysis, New York, W.H. Freeman.

Haydu, J. (2002), "Business Citizenship at Work: Cultural Transposition and Class Formation in Cincinnati 1870-1910", The Amercian Journal of Sociology 107:6, 1424-1467.

Hartmann, S. (2001), "Effective Field Theories, Reductionism and Scientific Explanation", Studies in History and Philosophy of Science 32:2, 267-304.

Hawking, S. / L. Mlodinow (2010), The Grand Design, New York, Bantam Books.

Hermans, T. (1999), Translation in Systems. Descriptive and System-Oriented Approaches Explained, Manchester, St. Jerome.

Hess, Ch. / E. Ostrom (2007), "Introduction. An Overview of the Knowledge Commons", in Understanding Knowledge as a Commons, by eds. Ch. Hess / E. Ostrom, 2-26, Cambridge (ma) / London, mit Press.

Holmes, J.S. (1988), Translated! Papers on Literary Translation and Translation Studies, Amsterdam, Rodopi.

Johnson, S. (2002), Emergence. The Connected Lives of Ants, Brains, Cities, and Software, New York, Touchstone.

Kahn, A. (2000), Kind of Blue. The Making of the Miles Davis Masterpiece, London, Granta Books.

Kampff Lages, S. (2007), Walter Benjamin. Tradução \& Melancolia, São Paulo, Editora da Universidade de São Paulo (EDUSP).

Kauffman, S. (2003), Investigaciones. Complejidad, autoorganización y nuevas leyes para una biología general, translated by L.E. de Juan Vidales, Barcelona, Tusquets.

Kitayama, Sh. / J. Park (2010), "Cultural Neuroscience of the Self: Understanding the Social Grounding of the Brain", Scan 5, 111-129. 
Klein, N. (2005), No Logo. El poder de las marcas, translated by A. Jockl, Barcelona, Paidós.

Kuhn, T.S. (2004), La estructura de las revoluciones científicas, translated by A. Contín, México, Fondo de Cultura Económica.

Lakatos, I. (1981), La crítica y la metodología de programas científicos de investigación, translated by J.M. Alcañiz, Valencia, Teorema.

Lotman, J.M. et alli (1979), Semiótica de la cultura, Madrid, Cátedra.

Luhmann, N. (1998), Die Gessellschaft der Gesellschaft, Frankfurt a.M., Suhrkamp.

-- (2006), Sociología del riesgo, translated by S. Pappe / Br. Erker / L.F. Segura / J. Torres Nafarrate, México, Universidad Iberoamericana.

Maestro, J.G. (2002), "La recuperación de la semiótica”, in Nuevas perspectivas en semiología literaria, by ed. J.G. Maestro, Madrid: Arco-Libros, 11-40.

Mahner, M. (2001), "Function and Functionalism. A Synthetic Perspective", Philosophy of Science 68, 75-94.

Marcus, Gr. (2012), “Cleaning Up Science”, New Yorker (24.12.2012), <http://www.newyorker.com/online/blogs/newsdesk/2012/12/cleaning-upscience.html> (viewed on: 12.01.2013).

Martín-Barbero, J. (2010), De los medios a las mediaciones. Comuncación, cultura y hegemonía, Barcelona, Anthropos.

Masterman, M. (1999), "The Nature of a Paradigm", in Criticism and the Growth of Knowledge, by eds. I. Lakatos / A. Musgrave, 59-90. Cambridge: Cambridge University Press. Merton, Robert K. (2002), Teoría y estructura sociales, translated by F.M. Torner / R. Borquee, México, Fondo de Cultura Económica.

Mlodinow, L. (2009), The Drunkard's Walk. How Randomness Rules Our Lives, New York, Vintage Books Edition.

Moreiras, A. (2007), "Transculturación e conciencia dobre", O espectro politico hoxe. 
Ilustración $\quad$ barbarie. Vigo: Universidade de Vigo, <http://www.uvigo.tv/gl/serial/254.html> (viewed on: 06.04.2008).

Mühlmann, H. (1996), The Nature of Cultures. A Blueprint for a Theory of Culture Genetics, translated by R. Payne, Wien, Springer-Verlag.

Neubert, A / G. Shreve (1994), “Foreword: 'A House of Many Rooms': the Range of Translation Studies", in Translating Slavery. Gender and Race in French Women's Writing 1783-1823, by eds. D. Kadish / F. Masserdier-Kenney, vii-xv, Kent / Ohio, Kent State University.

Nouss, A. (1995), "La traduction comme OVNI", Meta. Journal des traducteurs/ Meta. Translators' Journal 40:3, 335-342.

Nord, Ch. (1997), Translation as a Purposeful Activity. Functionalist Approaches Explained, Manchester, St. Jerome.

Nowotny, S. (2006), “'Culture' and the Analysis of Power", Transversal/ eipcp, Wien, European Institute for Progressive Cultural Policies, <http://translate.eipcp.net/strands/01/nowotny-strands01en> (viewed on: 03.02.2011).

Oksaar, E. (1995), Kulturemtheorie. Ein Beitrag zur Sprachverwendungsforschung, Hamburg / Göttingen, Vandenhoeck / Ruprecht.

Ostrom, E. (2009), “A General Framework for Analyzing Sustainability of Social-Ecological Systems", Science 325, 419-422.

Ostrom, E. / Ch. Hess (2007), "A Framework for Analyzing the Knowledge Commons”, in Understanding Knowledge as a Commons, by eds. Ch. Hess / E. Ostrom, 41-82, Cambridge (ma) / London: mit Press.

Paletz, S.B.F., Christian D. Schunn / Kevin H. Kim (2013), "The interplay of conflict and analogy in multidisciplinary teams", Cognition 126:1, 1-19.

Pardo, J.L. (2012), "La hipertrofia del presente". El País, <http://www.elpais.com/articulo/cultura/hipertrofia/presente/elpepicul/20120107elpep 
icul_1/Tes> (viewed on: 07.01.2012).

Parsons, T. (1999), El sistema social, translated by J. Jiménez Blanco / J. Cazorla Pérez, Madrid, Alianza.

Pérez Durán, G. (2008), A espiral posmoderna. Unha perspectiva da paratradución dende a neurociencia e a memética, unpublished PhD Dissertation, Universidade de Vigo.

Pérez Durán, G. (2012) “A configuración do campo de investigación da tradutoloxía: algúns problemas teóricos", in Sementar para os que veñan. Homenaxe a Camiño Noia, by eds. Bieito Arias Freixedo / Xosé María Gómez Clemente / Gabriel Pérez Durán, Vigo, Servizo de Publicacións da Universidade de Vigo.

Pietersee, (1995), “Globalization as Hybridization”, in Global Modernities, by eds. M. Featherstone / S. Lash / R. Robertson, 45-68, London, Sage.

Planck, M. (1936), The Philosophy of Physics, New York, Norton.

Reiss, K. / H.J. Vermeer (1996), Fundamentos para una teoría funcional de la tradución, translated by S. García Reina / C. Martín de León, Madrid, Akal.

Reynolds, S. (2011), Retromania. Pop Culture's Addiction to Its Own Past, New York, Faber \& Faber.

Robertson, R. (1995), “Glocalization: Time-Space and Homogeneity-Heterogeneity”, in M. Featherstone / S. Lash / R. Robertson, Global Modernities, London, Sage, 25-44.

Rule, N.O. / J.B. Freeman / N. Ambady (2013), "Culture in social neuroscience: A Review”, Social Neuroscience 8:1, 3-10.

Sapolsky, R.M. (2008), ¿Por qué las cebras no tienen úlceras? Guía del estrés, translated by C. González Serrano / M.A. Coll Rodríguez, Madrid, Alianza.

Sassen, S. (2010), Territorio, autoridad y derechos. De los ensamblajes medievales a los ensamblajes globales, translated by Mํㅡㅁ. Rodil, Buenos Aires, Katz.

Schäffner, Ch. (2007), "Politics and Translation", in A Companion to Translation Studies, by 
eds. P. Kuhiwczak / K. Littau, 134-147, Clevedon, Multilingual Matters.

Schrödinger, E. (1951), Science and Humanism. Physics in our Time, Cambridge, Cambridge University Press.

Sela-Sheffy, R. (2000), "The Suspended Potential of Culture Research in TS", Target 12:2, 345-354.

Seligman, R. / R.A. Brown (2010), "Theory and Method at the Intersection of Anthropology and Cultural Neuroscience", Scan 5, 130-137.

Silverstein, M. (2007), “Translation, Transduction, Transformation: Skating «Glossando» on Thin Semiotic Ice", in Translating Cultures. Perspectives on Translation and Anthropology, by eds. P.G. Rubel / A. Rosman, 75-105, Oxford, Berg.

Snell-Hornby, M. (2010), "The turns of Translation Studies", in Handbook of Translation Studies, vol. i. by eds. Y. Gambier / L.V. Doorslaer, 366-370, Amsterdam / Philadelphia, Benjamins.

Snow, C.P. (1959), The Two Cultures, Cambridge, Cambridge University Press.

Solé, R. (2009), Redes complejas. Del genoma a Internet, Barcelona, Tusquets.

Spivak, G.Ch. (1985), "Subaltern Studies. Deconstructing Historiography", in The Spivak Reader. Selected Works of Gayatri Chakravorty Spivak, by eds. D. Landry / G. MacLean, 203235, New York, Routledge.

Stewart, I. (2001), ¿Juega Dios a los dados?, translated by M. Ortuño / J. Ruiz Martínez / R. García Sanz, Barcelona, Crítica.

Taleb, N.N. (2008), El cisne negro. El impacto de lo altamente improbable, translated by R. Filella, Barcelona, Paidós.

Toury, G. (1995), Descriptive Translation Studies and Beyond, Amsterdam / Philadelphia, Benjamins.

Tymoczko, M. (2000), "Translation and Political Engagement: Activism, Social Change and 
the Role of Translation in Geopolitical Shifts", The Translator 6:1, 23-47.

Tyulenev, S. (2009), "Why (not) Luhmann? On the Aplicability of Social Systems Theory to Translation Studies", Translation Studies 2:2, 147-162.

-- (2010), “Is Translation an Autopoietic System?”, MonTI 2, 345-371.

-- (2011), Applying Luhmann to Translation Studies. Translation in Society, New York, Routledge.

Vermeer, H.J. (1983), "Translation Theory and Linguistics", in Häkökohtia käänämisen tutkimuksesta, by eds. P. Roinila / R. Orfanos / S. Tirkkonen-Condit, Joensuu, University of Joensuu / Publications of the Department of Languages.

Vidal Claramonte, A. (1998), El futuro de la traducción. Últimas teorías, nuevas aplicaciones, Valencia, Diputació de Valencia / Institució Alfons el Magnànim.

Walsh Hokenson, J. (2007), "Haiku as a Western genre. Fellow-traveller of modernism”, in Modernism, vol. ii, by eds. A. Eysteinsson / V. Liska, 693-714, Amsterdam / Philadelphia, Benjamins.

Willson, P. (2012), "Translation as a metaphor in scientific discourse", Translation. A Transdisciplinary Journal 2011, 82-83.

Wilss, W. (1999), “Interdisciplinarity in Translation Studies”, Target 11:1, 131-144.

Wing-Kwong Leung, M. (2006), “The Ideological Turn in Translation Studies”, in Translation Studies at the Interface of Disciplines, by eds. J. Ferreira Duarte / A. Assis Rosa / Teresa Seruya, 129-145, Amsterdam / Philadelphia, John Benjamins.

Wittgenstein, L. (1998), Investigaciones filosóficas, translated by A. García Suárez / U. Moulines, Barcelona, Crítica.

Wolf, M. / A. Fukari (eds.) (2007), Constructing a Sociology of Translation, Amsterdam / Philadelphia, Benjamins.

Wolf. M. (2000), “The Third Space in Postcolonial Representation”, in Changing the Terms. Translating in the Postcolonial Era, by eds. Sh. Simon / P. St-Pierre, 127-146, Ottawa, 
University of Ottawa Press.

Wolf, M. (2002), "Culture as Translation-and Beyond Ethnographic Models of Representation in Translation Studies", in Crosscultural Transgressions. Research Models in Translation Studies II. Historical and Ideological Issues, by ed. Th. Hermans, 180-192, Manchester (UK) / Northampton (MA), St. Jerome.

Wolf, M. (2007), "Introduction: The Emergence of a Sociology of Translation", in Constructing a Sociology of Translation, by eds. M. Wolf / A. Fukari, 1-38, Amsterdam / Philadelphia, Benjamins.

Gabriel Pérez recebeu o grau de Mestre em Filosofia Galega, em 2006, e o Diploma de Estudos Avançados, em 2008, pela Universidade de Vigo, onde completa atualmente uma tese de doutoramento sobre as relações entre a música e a tradução utilizando métodos aplicados das ciências e das humanidades. Exerceu funções docentes nas universidades de Vigo, Viena e Heidelberg, onde leciona no departamento de Estudos Românicos. É crítico literário das publicações ProTexta, Anuario Grial de Estudios Literarios e Grial. Publicou vários artigos sobre a dramaturgia de Xohana Torres, sobre a Terceira Cultura e sobre Música. No campo musical foi membro de vários grupos, praticando estilos variados, do clássico ao tradicional e ao experimental. Enquanto programador de aplicações digitais desenvolveu, com os seus alunos da Universidade de Heidelberg, uma aplicação (app) pedagógica intitulada O Ximnasio dos Verbos [Gym of Verbs]. 


\section{Bibliography}

Appadurai, A. (1996), Modernity at Large. Cultural Dimensions of Globalization, Minneapolis, University Minnesota Press.

Aunger, R. (2004), El meme eléctrico. Una nueva teoría sobre cómo pensamos, translated by J. Ros, Barcelona, Paidós.

Badiou, A. (1999), El Ser y el Acontecimiento, translated by R.J. Cerdeiras / A.A. Cerletti, Buenos Aires: Manantial.

Baltrusch, B. (2007), “Teoria e prática da Tradução \& Paratradução de literaturas e culturas contemporâneas", À Beira 6, 11-53.

-- / G. Pérez Durán (2010), “Na orografía do mudable. Cara a uns Estudos de Tradución \& Paratradución", in Soldando Sal. Galician Studies in Translation and Paratranslation, by eds. B. Baltrusch / G. Pérez Durán / K. Sartingen, 9-33, Munich: Martin Meidenbauer Verlag.

Bachmann-Medick, D. (2009), “Introduction. The Translation Turn”, Translation Studies 2:1, 2-16.

Baker, M. (1996), “Linguistics and Cultural Studies: Complementary or Competing Paradigms in Translation Studies?, in A. Lauer et al., Übersetzungswissenschaft im Umbrach. Festschrift für Wolfram Wills zum 70, Tübingen, Gunter Narr Verlag, 9-19.

Barabási, A-L. (2003). Linked. How Everything is Connected to Everything Else and What It Means for Business, Science, and Everyday Life, New York, Plume.

Bassnett, S. / A. Lefevere (eds.) (1990), Translation, History and Culture, London, Pinter.

Bassnett, S. (1998), “The Translation Turn in Cultural Studies”, in Constructing Cultures. Essays on Literary Translation, by eds. S. Bassnett / A. Lefevere, 123-140, Clevedon, Multilingual Matters.

-- (1999), “Translation 2000. Difference and Diversity”, Textus 12/2, 213-218.

Benjamin, W. (1992), Sobre Arte, Técnica, Linguagem e Política, translated by Ma Luz Moita / N. 37 - 12/ 2017 | 73-106 - ISSN 2183-2242 | http:/dx.doi.org/10.21747/21832242/litcomp37a4 97 
MaA. Cruz / M. Alberto, Lisboa, Relógio d'Agua.

-- (2007), “'A tarefa de quen traduce' von de Walter Benjamin”, translated by B. Baltrusch / S. Montero Küpper / X.M. Garrido Vilariño, Viceversa 13, 79-103.

Bertalanffy, L. von (1976), Teoría general de los sistemas. Fundamentos, desarrollo, aplicaciones, translated by J. Almela, México, Fondo de Cultura Económica.

Bilbao, H. / A. Hax (2012), "Richard Sennett: 'Hay que perder el miedo al fracaso'”, Clarín (27.07.2012), <http://www.revistaenie.clarin.com/ideas/Richard-Sennett-entrevistasociologia-buenos-aires_0_745125489.html> (viewed on: 01.08.2012).

Bowker, L. / M. Cronin / D. Kenny / J. Pearson (eds.) (1998), Unity in Diversity? Current Trends in Translation Studies, Manchester, St. Jerome.

Brockman, J. (1996), "Introducción. La tercera cultura que emerge”, In La tercera cultura. Más allá de la revolución científica, by ed. J. Brockman, 13-26, translated by A. García, Barcelona, Tusquets.

Buden, B. (2005), "The Pit of Babel or: The Society that Mistook Culture for Politics", Transversal/ eipcp, translated by A. Derieg, Wien, European Institute for Progressive Cultural Policies, <http://translate.eipcp.net/strands/01/buden-strands01en> (viewed on: 03.02.2011).

-- (2006), "Cultural Translation: Why It is Important and Where to Start With It", Transversal/ eipcp. Wien: European Institute for Progressive Cultural Policies, <http://translate.eipcp.net/transversal/0606/buden/en> (viewed on: 03.02.2011).

Bueno, G. (1992), Teoría del cierre categorial. Introducción general. Siete enfoques en el estudio de la ciencia, vol. i, Oviedo, Pentalfa.

-- (1993), Teoría del cierre categorial, vol. II, Oviedo, Pentalfa.

Bunge, M. (2010), Matter and Mind. Philosophical Inquiry, Boston, Springer.

-- (2011), 100 ideas. El libro para pensar y discutir en el café, Buenos Aires, Editorial Sudamericana. 
Burke, P. (2010), Hibridismo cultural, translated by S. Chaparro Martínez, Madrid, Akal.

Camazine, S. / J-L. Deneubourg, N.R. / Franks, J. Sneyd / G. Theraulaz / E. Bonabeau (2001), Self-Organization in Biological Systems, Princeton, Princeton University Press.

Campos, H. de (1992), "Da tradução como criação e como crítica", in H. de Campos, Metalinguagem \& Outras Metas, São Paulo, Perspectiva, 31-48.

Chesterman, A. / R. Arrojo (2000), "Shared Ground in Translation Studies", Target 12:1, 151-160.

Das, V. (2002), “Violence and Translation”, Anthropological Quarterly 75:1, 105-112.

Diamond, J. (1997), Guns, Germs, and Steel. The Fates of Human Societies, New York, W.W. Norton.

Dolezel, L. (1986), “Semiotics of Literary Communication”, Strumenti Critici 50, 5-48.

-- (1997), Historia breve de la poética, translated by L. Alburquerque, Madrid, Síntesis.

Even-Zohar, I. (1981), “Translation Theory Today. A Call for Transfer Theory”, Poetics Today $2: 4,1-7$.

-- (1997), “The Making of Culture Repertoire and the Role of Transfer", Target 9:2, 373-381.

Feyerabend, P.K. (1986), Tratado contra el método. Esquema de una teoría anarquista del conocimiento, translated by D. Ribes, Madrid, Tecnos.

Fleck, L. (1986), La génesis y el desarrollo de un hecho científico, translated by L. Meana / A. González de Pablo, Madrid, Alianza.

Friedman, J. (1995), "Global System, Globalization and the Parameters of Modernity", in M. Featherstone / S. Lash / R. Robertson, Global Modernities, London, Sage, 69-90.

Genette, G. (1989), Palimpsestos. La literatura en segundo grado, translated by C. Fernández Prieto, Madrid, Taurus.

Gentzler, E. (2001), “Expanding Horizons or Limiting Growth?”, Target 13:1, 160-165.

Gould, S.J. (2007), La estructura de la teoría de la evolución, translated by A. García Leal, 
Barcelona, Tusquets.

Griffiths, A. J.F. / J.H. Miller / D.T. Suzuki / R.C. Lewontin / W.M. Gelbart (2000), $A n$ Introduction to Genetic Analysis, New York, W.H. Freeman.

Haydu, J. (2002), "Business Citizenship at Work: Cultural Transposition and Class Formation in Cincinnati 1870-1910", The Amercian Journal of Sociology 107:6, 1424-1467.

Hartmann, S. (2001), "Effective Field Theories, Reductionism and Scientific Explanation", Studies in History and Philosophy of Science 32:2, 267-304.

Hawking, S. / L. Mlodinow (2010), The Grand Design, New York, Bantam Books.

Hermans, T. (1999), Translation in Systems. Descriptive and System-Oriented Approaches Explained, Manchester, St. Jerome.

Hess, Ch. / E. Ostrom (2007), "Introduction. An Overview of the Knowledge Commons", in Understanding Knowledge as a Commons, by eds. Ch. Hess / E. Ostrom, 2-26, Cambridge (ma) / London, mit Press.

Holmes, J.S. (1988), Translated! Papers on Literary Translation and Translation Studies, Amsterdam, Rodopi.

Johnson, S. (2002), Emergence. The Connected Lives of Ants, Brains, Cities, and Software, New York, Touchstone.

Kahn, A. (2000), Kind of Blue. The Making of the Miles Davis Masterpiece, London, Granta Books.

Kampff Lages, S. (2007), Walter Benjamin. Tradução \& Melancolia, São Paulo, Editora da Universidade de São Paulo (EDUSP).

Kauffman, S. (2003), Investigaciones. Complejidad, autoorganización y nuevas leyes para una biología general, translated by L.E. de Juan Vidales, Barcelona, Tusquets.

Kitayama, Sh. / J. Park (2010), “Cultural Neuroscience of the Self: Understanding the Social Grounding of the Brain", Scan 5, 111-129. 
Klein, N. (2005), No Logo. El poder de las marcas, translated by A. Jockl, Barcelona, Paidós.

Kuhn, T.S. (2004), La estructura de las revoluciones científicas, translated by A. Contín, México, Fondo de Cultura Económica.

Lakatos, I. (1981), La crítica y la metodología de programas científicos de investigación, translated by J.M. Alcañiz, Valencia, Teorema.

Lotman, J.M. et alli (1979), Semiótica de la cultura, Madrid, Cátedra.

Luhmann, N. (1998), Die Gessellschaft der Gesellschaft, Frankfurt a.M., Suhrkamp.

-- (2006), Sociología del riesgo, translated by S. Pappe / Br. Erker / L.F. Segura / J. Torres Nafarrate, México, Universidad Iberoamericana.

Maestro, J.G. (2002), "La recuperación de la semiótica”, in Nuevas perspectivas en semiología literaria, by ed. J.G. Maestro, Madrid: Arco-Libros, 11-40.

Mahner, M. (2001), "Function and Functionalism. A Synthetic Perspective", Philosophy of Science 68, 75-94.

Marcus, Gr. (2012), “Cleaning Up Science”, New Yorker (24.12.2012), <http://www.newyorker.com/online/blogs/newsdesk/2012/12/cleaning-upscience.html> (viewed on: 12.01.2013).

Martín-Barbero, J. (2010), De los medios a las mediaciones. Comuncación, cultura y hegemonía, Barcelona, Anthropos.

Masterman, M. (1999), "The Nature of a Paradigm", in Criticism and the Growth of Knowledge, by eds. I. Lakatos / A. Musgrave, 59-90. Cambridge: Cambridge University Press. Merton, Robert K. (2002), Teoría y estructura sociales, translated by F.M. Torner / R. Borquee, México, Fondo de Cultura Económica.

Mlodinow, L. (2009), The Drunkard's Walk. How Randomness Rules Our Lives, New York, Vintage Books Edition.

Moreiras, A. (2007), "Transculturación e conciencia dobre", O espectro politico hoxe. 
Gabriel Perez

Ilustración $e$ barbarie. Vigo: Universidade de Vigo, <http://www.uvigo.tv/gl/serial/254.html> (viewed on: 06.04.2008).

Mühlmann, H. (1996), The Nature of Cultures. A Blueprint for a Theory of Culture Genetics, translated by R. Payne, Wien, Springer-Verlag.

Neubert, A / G. Shreve (1994), "Foreword: 'A House of Many Rooms': the Range of Translation Studies", in Translating Slavery. Gender and Race in French Women's Writing 1783-1823, by eds. D. Kadish / F. Masserdier-Kenney, vii-xv, Kent / Ohio, Kent State University.

Nouss, A. (1995), "La traduction comme OVNI", Meta. Journal des traducteurs/ Meta. Translators' Journal 40:3, 335-342.

Nord, Ch. (1997), Translation as a Purposeful Activity. Functionalist Approaches Explained, Manchester, St. Jerome.

Nowotny, S. (2006), “'Culture' and the Analysis of Power", Transversal/ eipcp, Wien, European Institute for Progressive Cultural Policies, <http://translate.eipcp.net/strands/01/nowotny-strands01en> (viewed on: 03.02.2011).

Oksaar, E. (1995), Kulturemtheorie. Ein Beitrag zur Sprachverwendungsforschung, Hamburg / Göttingen, Vandenhoeck / Ruprecht.

Ostrom, E. (2009), “A General Framework for Analyzing Sustainability of Social-Ecological Systems", Science 325, 419-422.

Ostrom, E. / Ch. Hess (2007), "A Framework for Analyzing the Knowledge Commons”, in Understanding Knowledge as a Commons, by eds. Ch. Hess / E. Ostrom, 41-82, Cambridge (ma) / London: mit Press.

Paletz, S.B.F., Christian D. Schunn / Kevin H. Kim (2013), "The interplay of conflict and analogy in multidisciplinary teams", Cognition 126:1, 1-19.

Pardo, J.L. (2012), "La hipertrofia del presente". El País, <http://www.elpais.com/articulo/cultura/hipertrofia/presente/elpepicul/20120107elpep 
icul_1/Tes> (viewed on: 07.01.2012).

Parsons, T. (1999), El sistema social, translated by J. Jiménez Blanco / J. Cazorla Pérez, Madrid, Alianza.

Pérez Durán, G. (2008), A espiral posmoderna. Unha perspectiva da paratradución dende a neurociencia e a memética, unpublished PhD Dissertation, Universidade de Vigo.

Pérez Durán, G. (2012) “A configuración do campo de investigación da tradutoloxía: algúns problemas teóricos", in Sementar para os que veñan. Homenaxe a Camiño Noia, by eds. Bieito Arias Freixedo / Xosé María Gómez Clemente / Gabriel Pérez Durán, Vigo, Servizo de Publicacións da Universidade de Vigo.

Pietersee, (1995), “Globalization as Hybridization”, in Global Modernities, by eds. M. Featherstone / S. Lash / R. Robertson, 45-68, London, Sage.

Planck, M. (1936), The Philosophy of Physics, New York, Norton.

Reiss, K. / H.J. Vermeer (1996), Fundamentos para una teoría funcional de la tradución, translated by S. García Reina / C. Martín de León, Madrid, Akal.

Reynolds, S. (2011), Retromania. Pop Culture's Addiction to Its Own Past, New York, Faber \& Faber.

Robertson, R. (1995), “Glocalization: Time-Space and Homogeneity-Heterogeneity”, in M. Featherstone / S. Lash / R. Robertson, Global Modernities, London, Sage, 25-44.

Rule, N.O. / J.B. Freeman / N. Ambady (2013), "Culture in social neuroscience: A Review”, Social Neuroscience 8:1, 3-10.

Sapolsky, R.M. (2008), ¿Por qué las cebras no tienen úlceras? Guía del estrés, translated by C. González Serrano / M.A. Coll Rodríguez, Madrid, Alianza.

Sassen, S. (2010), Territorio, autoridad y derechos. De los ensamblajes medievales a los ensamblajes globales, translated by Mํㅡㅁ. Rodil, Buenos Aires, Katz.

Schäffner, Ch. (2007), "Politics and Translation", in A Companion to Translation Studies, by 
eds. P. Kuhiwczak / K. Littau, 134-147, Clevedon, Multilingual Matters.

Schrödinger, E. (1951), Science and Humanism. Physics in our Time, Cambridge, Cambridge University Press.

Sela-Sheffy, R. (2000), "The Suspended Potential of Culture Research in TS", Target 12:2, 345-354.

Seligman, R. / R.A. Brown (2010), "Theory and Method at the Intersection of Anthropology and Cultural Neuroscience", Scan 5, 130-137.

Silverstein, M. (2007), “Translation, Transduction, Transformation: Skating «Glossando» on Thin Semiotic Ice", in Translating Cultures. Perspectives on Translation and Anthropology, by eds. P.G. Rubel / A. Rosman, 75-105, Oxford, Berg.

Snell-Hornby, M. (2010), "The turns of Translation Studies", in Handbook of Translation Studies, vol. i. by eds. Y. Gambier / L.V. Doorslaer, 366-370, Amsterdam / Philadelphia, Benjamins.

Snow, C.P. (1959), The Two Cultures, Cambridge, Cambridge University Press.

Solé, R. (2009), Redes complejas. Del genoma a Internet, Barcelona, Tusquets.

Spivak, G.Ch. (1985), "Subaltern Studies. Deconstructing Historiography”, in The Spivak Reader. Selected Works of Gayatri Chakravorty Spivak, by eds. D. Landry / G. MacLean, 203235, New York, Routledge.

Stewart, I. (2001), ¿Juega Dios a los dados?, translated by M. Ortuño / J. Ruiz Martínez / R. García Sanz, Barcelona, Crítica.

Taleb, N.N. (2008), El cisne negro. El impacto de lo altamente improbable, translated by R. Filella, Barcelona, Paidós.

Toury, G. (1995), Descriptive Translation Studies and Beyond, Amsterdam / Philadelphia, Benjamins.

Tymoczko, M. (2000), "Translation and Political Engagement: Activism, Social Change and 
the Role of Translation in Geopolitical Shifts", The Translator 6:1, 23-47.

Tyulenev, S. (2009), "Why (not) Luhmann? On the Aplicability of Social Systems Theory to Translation Studies", Translation Studies 2:2, 147-162.

-- (2010), “Is Translation an Autopoietic System?”, MonTI 2, 345-371.

-- (2011), Applying Luhmann to Translation Studies. Translation in Society, New York, Routledge.

Vermeer, H.J. (1983), "Translation Theory and Linguistics”, in Häkökohtia käänämisen tutkimuksesta, by eds. P. Roinila / R. Orfanos / S. Tirkkonen-Condit, Joensuu, University of Joensuu / Publications of the Department of Languages.

Vidal Claramonte, A. (1998), El futuro de la traducción. Últimas teorías, nuevas aplicaciones, Valencia, Diputació de Valencia / Institució Alfons el Magnànim.

Walsh Hokenson, J. (2007), "Haiku as a Western genre. Fellow-traveller of modernism", in Modernism, vol. ii, by eds. A. Eysteinsson / V. Liska, 693-714, Amsterdam / Philadelphia, Benjamins.

Willson, P. (2012), "Translation as a metaphor in scientific discourse", Translation. A Transdisciplinary Journal 2011, 82-83.

Wilss, W. (1999), “Interdisciplinarity in Translation Studies”, Target 11:1, 131-144.

Wing-Kwong Leung, M. (2006), “The Ideological Turn in Translation Studies”, in Translation Studies at the Interface of Disciplines, by eds. J. Ferreira Duarte / A. Assis Rosa / Teresa Seruya, 129-145, Amsterdam / Philadelphia, John Benjamins.

Wittgenstein, L. (1998), Investigaciones filosóficas, translated by A. García Suárez / U. Moulines, Barcelona, Crítica.

Wolf, M. / A. Fukari (eds.) (2007), Constructing a Sociology of Translation, Amsterdam / Philadelphia, Benjamins.

Wolf. M. (2000), "The Third Space in Postcolonial Representation”, in Changing the Terms. Translating in the Postcolonial Era, by eds. Sh. Simon / P. St-Pierre, 127-146, Ottawa, 
University of Ottawa Press.

Wolf, M. (2002), “Culture as Translation-and Beyond Ethnographic Models of Representation in Translation Studies", in Crosscultural Transgressions. Research Models in Translation Studies II. Historical and Ideological Issues, by ed. Th. Hermans, 180-192, Manchester (UK) / Northampton (MA), St. Jerome.

Wolf, M. (2007), "Introduction: The Emergence of a Sociology of Translation", in Constructing a Sociology of Translation, by eds. M. Wolf / A. Fukari, 1-38, Amsterdam / Philadelphia, Benjamins.

Gabriel Pérez recebeu o grau de Mestre em Filosofia Galega, em 2006, e o Diploma de Estudos Avançados, em 2008, pela Universidade de Vigo, onde completa atualmente uma tese de doutoramento sobre as relações entre a música e a tradução utilizando métodos aplicados das ciências e das humanidades. Exerceu funções docentes nas universidades de Vigo, Viena e Heidelberg, onde leciona no departamento de Estudos Românicos. É crítico literário das publicações ProTexta, Anuario Grial de Estudios Literarios e Grial. Publicou vários artigos sobre a dramaturgia de Xohana Torres, sobre a Terceira Cultura e sobre Música. No campo musical foi membro de vários grupos, praticando estilos variados, do clássico ao tradicional e ao experimental. Enquanto programador de aplicações digitais desenvolveu, com os seus alunos da Universidade de Heidelberg, uma aplicação (app) pedagógica intitulada O Ximnasio dos Verbos [Gym of Verbs]. 